\title{
Artikel Manajemen Mutu Terpadu
}

Pelaksanaan Permasalahan Serta Solusi Manajemen Mutu Terpadu dalam Sistem Pendidikan

Widiyati Noverta

Universitas Negeri Padang

Indonesia

Email :

widiyatinoverta@gmail.co
Hade Afriansyah

Universitas Negeri Padang

Indonesia

Email :

hadeafriansyah@fip.ac.id
Rusdinal

Universitas Negeri Padang

Indonesia

Email :

rusdinalhar@yahoo.com

$\underline{\mathrm{m}}$

\section{ABSTRAK}

In carrying out the education process, it will not be separated from the improvement in accordance with the problems faced each year or in accordance with the application of TQM in school schools has the main goal of providing satisfaction to customers of internal and external education services with quality product results. Implementation of Total Quality Management in schools requires at least three stages of implementation, namely: preparation, planning, and implementation. Obstacles to the implementation of Total Quality Management in schools include the refusal to change, lack of commitment to quality, and lack of readiness, willingness and human competency. Alternative solutions need to be informed of the importance of
\end{abstract}

change in achieving quality, maintaining and developing it, so that a shared commitment to quality grows.

Kata Kunci: Total Quality Manajement , Education Quality Improvement.

\section{PENDAHULUAN}

Gerakan peningkatan mutu pendidikan perlu diawali dengan adanya reformasi dalam penyelenggaraan pendidikan di sekolah atau madrasah sebagai lembaga atau institusi yang memberikan layanan pendidikan apabila pendidikan kita ingin lebih bermutu. Untuk menghasilkan kualitas yang terbaik diperlukan upaya perbaikan berkesinambungan terhadap kemampuan manusia, proses, dan lingkungan. 
Salah satu cara terbaik sebagi upaya memperbaiki kemampuan komponen-komponen tersebut secara berkesinambungan adalah dengan cara menerapkan konsep Total Quality Manajement.

Menurut Rusdinal (Rusdinal, 2015) Pendidikan juga merupakan faktor utama dalam pembentukan pribadi manusia. Pendidikan sangat berperan dalam membentuk baik atau buruknya pribadi manusia menurut ukuran normatif. Prayitno(Rusdinal, 2015) menjelaskan bahwa tujuan pendidikan pada dasarnya adalah arah yang hendak dicapai demi terwujudnya tujuan hidup manusia, yaitu hidup sesuai Harkat dan Martabat Manusia (HMM), dengan segenap kandungannya, dimensi kemanusiaan dan pancadaya.

Pendidikan sebagai produk jasa selalu dituntut untuk dapat memberikan kepuasan kepada para konsumennya, dan hal itu harus dilakukan apabila tidak ingin ditinggal oleh pelanggan. Upaya untuk mencapai kondisi tersebut dengan mengadakan perubahan- perubahan, antara lain dengan mengimplementasikan Manajemen Mutu Terpadu ( Total Quality Manajement ) dalam dunia pendidikan.

$$
\text { Faktor yang mendorong }
$$
diimplementasikannya Total Quality Manajement (TQM) dalam dunia pendidikan adalah adanya kekuatan faktor eksternal (berasal dari luar oraganisasi), di samping faktor eksternal, ada kekuatan faktor internal yang juga dapat mendorong perlunya implemenatsi Total Quality Manajement (TQM) dalam dunia pendidikan, yaitu adanya masalah sumber daya manusia dan perilaku atau keputusan manajerial. Dengan demikain menjadi kebutuhan yang mendesak untuk diimplementasikan Manajemen Mutu Terpadu ( Total Quality Manajement ) di sekolah.

\section{METODE}

Artikel ini ditulis dengan tujuan untuk mengetahui bagaimana implementasi manajemen mutu terpadu dalam sistem pendidikan dan apa saja permasalahan-permasalah yang terjadi dalam penerapan manajemen mutu terpadu tersebut sera bagaimana pemecahan atau penyelesaian dari permasalahan tersebut. Artikel ini ditulis berdasarkan data-data baik itu kualitatif maupun kuantitatif dan bahan - bahan yang berhubungan dengan kajian yang akan ditinjau.

\section{KAJIAN TEORI DAN PEMBAHASAN}

A. Total Quality Manajement dalam Konteks Pendidikan

Total Quality Management dalam kontek pendidikan merupakan sebuah filosofi metodologi tentang perbaikan secara terus menerus, yang dapat memberikan seperangkat alat praktis kepada setiap institutsi pendidikan dalam memenuhi kebutuhan, keinginan,, dan harapan pelanggan, saat ini maupun masa yang akan datang. Suatu pendekatan,Total Quality Manajement (TQM) memiliki sistem manajemen yang mampu mengangkat kualitas sebagai strategi usaha yang berorinetasi pada kepuasan pelanggan dengan cara melibatkan seluruh anggota 
organisasi atau institusi. (TQM) merupakan sebuah filosofi tentang perbaikan secara terus menerus, yang dapat memberikan seperangkat alat praktis kepada setiap institusi pendidikan dalam memenuhi kebutuhan, keinginan, dan harapan para pelanggan saat ini dan masa yang akan datang.

B. Implementasi Total Quality Manajement di Sekolah

Dalam penerapan pengendalian manajemen mutu terpadu pada organisasi non profit seperti di sekolah sudah barang tentu tidak sama persis dengan yang diterapkan di dalam organisasi profit (dunia bisnis) pada umumnya, karena perlu disesuaikan dengan situasi dan kondisi yang ada, serta menyesuaikan dengan kebutuhan yang relevan dengan usaha peningkatan kualitas/mutu pendidikan di sekolah, di samping adanya perbedaan dalam menginterpretasikan pengertian kualitas/mutu sebagai terminologi kunci utama.

Total Quality Manajement (TQM) terfokus pada pengupayaan kepuasan pelanggan, dengan hasil produk yang berkualitas atau bermutu. Kata kunci quality atau mutu dalam Total Quality Manajement perlu diuraikan agar dapat digunakan dalam menjembatani pengimplentasiannya di lingkungan organisasi atau lembaga non profit khususnya di bidang pendidikan. Pengertian kualitas sebagaimana tersebut di atas jelas berorientasi pada organisasi profit dalam menjalankan proses produksi, yang menunjukkan bahwa kondisi produk sebagai hasilnya harus memenuhi beberapa tolok ukur tertentu. Di antara tolok ukur yang dimaksud adalah terpenuhinya persyaratan yang dituntut konsumen pada produk tersebut. Tolok ukur yang lain meliputi kondisi kemampuan memenuhi persyaratan yang dituntut oleh konsumen sejak awal dan secara terus menerus sesuai keinginan dan kebutuhannya yang selalu dapat berubah dan berkembang.

Filosifi Total Quality Manajement dalam pendidikan yang arahnya untuk memenuhi kebutuhan pelanggan, maka budaya kerja yang mantab harus terbina dan berkembang dengan baik dari seluruh tenaga pendidik dan kepenidikan yang terlibat. Motivasi, sikap, kemauan dan dedikasi untuk memenuhi kebutuhan pelanggan adalah bagian terpenting dari budaya kerja yang bermutu.

Menurut Afriansyah (Afriansyah, 2019) dalam melaksanakan ataupun mengimplementasikan Total Quality Manajement (TQM) hendaknya dilakukan dengan memperhatikan prinsip : 1). Pelaksanaan harus sesuai dengan perencanan, 2). Pengawasan dan evaluasi memungkinkan untuk perubahan pelaksanaan dengan terlebih dahulu 
mengubah perencanaan, 3). Agar

pelaksanaan dapat berjalan baik sesuai dengan rencana dibutuhkan kematangan organisasi.

\section{Implementasi TQM dan peningkatan mutu pendidikan}

Implementasi manajemen mutu terpadu artinya adanya upaya mengadakan perubahan sistem manajemen yang telah ada dan mapan, dari sistem manajemen tradisional/manajemen lainnya beralih ke sistem manajemen baru yaitu Total Qua lity Manajement (TQM). Sedangkan untuk mengimplementasikan TQM diperlukan komitmen jangka panjang dan perubahan total atas sistem yang telah ada, maka dipandang perlu untuk diketahui perbedaan paradigma Total Quality Manaj ement (TQM) dengan paradigma manajemen lainya.

Total Quality Manajement tidak mengabaikan pembahasan masalah input (peserta didik) dan outut (lulusan), tetapi terpusat pada pelanggan yang memiliki kebutuhan dan bagaimana cara memuaskan pelanggan. Adanya pendapat yang menyatakan bahwa lulusan merupakan produk pendidikan pada kenyataanya memiliki kelemahan-kelemahan yang mendasar. Menurut Permadi sebagaimana dikutip Mulyasa karena "Lulusan peserta didik yang telah menyelesaikan pendidikannya adalah individu yang perilaku dan perbuatnnya sesungguhnya bukan hanya dipengaruhi ilmu dan keterampilan yang diperolehnya selama pendidikan, melainkan juga dipengaruhi oleh berbagai faktor lain, termasuk motivasi kerja, sikap, dan latar belakang budaya serta pengaruh lingknugan“. Dengan demikian pendidikan yang berkualitas tidak hanya dilihat dari mutu lulusannya saja, melainkan dapat dilihat dari bagaimana lembaga pendidikan tersebut mampu memenuhi kebutuhan pelanggan sesuai dengan standar mutu yang berlaku.

Implementasi Total Quality Manajement memerlukan kesungguhan dari semua pihak dalam pelaksanaanya, dan merupakan suatu proses yang relatif panjang. Sehubungan dengan hal itu, top manajer harus melibatkan partisipasi aktif dari seluruh guru, staf dan karyawan, sehingga tumbuh komitmen yang tinggi terhadap pencapaian tujuan.

D. Hambatan dan Pemecahannya

Menurut Surahyo (Surahyo, 2015) dimungkinkan akan muncul hambatan-hambatan tentang implementasi Total Quality Manajement dalam bidang pendidikan, antara lain:

1. Persepsi atau interpretasi guru dan tenaga kependidikan lainnya terhadap perubahan sangat mempengaruhi penolakan terhadap perubahan. Untuk mengatasi penolakan tersebut, maka seorang manajer/kepala sekolah sangat diharapkan untuk dapat memberikan informasi yang mendalam tentang perubahan tersebut, menyampaikan alasan atau dasar pemikiran perlunya dilakukan perubahan, melakukan pertemuan tertentu dengan seluruh guru dan tenaga kependidikan lainnya untuk 
membahas setiap perubahan dan kemungkinan pengaruhnya terhadap mereka.

2. Belum adanya kebersamaan sikap terhadap kualitas. Kesadaran akan adanya kualitas dalam organisasi bergantung pada banyak faktor yang saling terkait dan mempengaruhi, terutama sikap kepala sekolah terhadap kualitas. Ketika ada komitmen dari semua personal, guru dan tenaga kependidikan yang terkait dalam meningkatakan kualitas pendidikan di sekolah melalui implementasi Total Quality Manajement, maka akan dapat berjalan dengan baik. Akan tetapi, apabila sebagian saja dari mereka tidak memiliki komitmen tersebut, apalagi jika seorang kepala sekolah selaku top manajer tidak memiliki komitmen terhadap mutu, jelas akan menjadi penghambat utama dalam mengimplementasikan Total Quality Manajement di sekolah. Dengan melihat kondisi tersebut di atas, maka perlu dibangun komitmen bersama untuk mengimplementasikan Total Quality Manajement di sekolah yang diawalai dari kepala sekolah selaku top manajer. Kepala sekolah perlu memiliki karakteristik pribadi yang mencakup: motivasi untuk memimpin, kejujuran, integritas, kepercayaan diri, inisiatif, kreativitas, kemampuan kognitif, pengetahuan bisnis, dan kharisma. Kualitas kepala sekolah tersebut dapat memberikan inspirasi pada semua jajaran manajemen agar memperagakan kualitas kepemimipinan yang sama yang diperlukan untuk mengembangkan budaya Total Quality Manajement .
3. Sumber daya manusia merupakan modal dasar dalam setiap organisasi yang sangat berpengaruh terhadap berjalan tidaknya suatu program dalam mencapai tujuan. Sukses tidaknya pengimplementasian Total Qualit Manajement di sekolah sangat ditentukan oleh kesiapan, kesediaan dan kompetensi kepala sekolah dan tenaga kependidikan di sekolah yang bersangkutan untuk sungguh-sungguh merealisasikannya.

Di sekolah karakteristik Total Quality Manajement ini bertolak dari asumsi berapapun besar jumlah dana yang disediakan, lengkapnya aset, canggihnya tekonologi yang tersedia, maka akan tidak ada artinya sama sekali, tidak bernilai, bahkan tidak berfungsi apabila yang mendayagunakannya terdiri dari sumber daya manusia (SDM) yang rendah kualitasnya. Oleh karena itu, kemungkinan adanya kendala kesiapan dan kesediaan sumber daya manusia harus diatasi, yaitu dengan cara memberikan informasi secara terus menerus dari kepala sekolah mengenai pentingnya implementasi Total Quality Manajement di sekolah dalam upaya meningkatkan mutu pendidikan.

Adapun untuk meningkatkan kualitas sumber daya manusia dalam rangka memberdayakannya dapat dilakukan melalui kegiatan pelatihan untuk setiap jenjang jabatan dan fungsi organisasi secara berkelanjutan. Pelatihan selain difokuskan pada peningkatan kualitas sumber daya manusia sesuai kebutuhan organisasi masa sekarang, juga diarahkan pada 
pengembangan kemampuan potensial untuk mengantisipasi perubahan dan perkembangan lingkungan di masa depan. Berdasarklan uraian tersebut di atas, bahwa implementasi Total Quality Manajement kemungkinan menghadapi hambatan atau kendala.

Hambatan yang muncul akan tidak ada artinya jika dapat terbentuk komitmen bersama terhadap kualitas. Dengan sikap tersebut akan menumbuhkan kekuatan yang besar untuk mengimplementasikan Total Quality Manajement di sekolah yang dipercayai dapat memberikan harapan adanya peningkatan mutu pendidikan di sekolah. Sedangkan untuk mengadakan perubahan dengan mengimplementasikan Total Quality Manajement bukanlah suatu pekerjaan yang mudah, oleh karena itu sangat diperlukan komitmen jangka panjang dari semua personal yang terlibat

\section{KESIMPULAN}

Tujuan utama dari pengimplementasian Total Quality Manajement di sekolah adalah untuk memberikan kepuasan terhadap pelanggan jasa pendidikan baik internal maupun eksternal dengan hasil produk yang bermutu. Untuk mengimplementasikan Total Qua lity Manajement di sekolah dibutuhkan sedikitnya tiga tahapan pelaksanaan, yaitu: 1) Tahap persiapan; 2) Tahap perencanaan; dan 3) Tahap pelaksanaan.

Hambatan yang mungkin muncul dengan adanya implementasi Total Quality Manajement di sekolah, antara lain adanya penolakan terhadap perubahan, belum adanya komitmen terhadap mutu, serta kurangnya kesiapan, kesediaan dan kompetensi sumbar daya manusia. Mengatasi hal tersebut perlu adanya informasi terus menerus tentang pentingnya perubahan untuk mencapai kualitas mutu, mempertahankan dan mengembangkannya, sehingga tumbuh komitmen bersama terhadap mutu. Di samping itu perlu diadakan pelatihan bagi semua guru dan tenaga kependidikan yang ada dalam rangka meningkatkan kualitas sumber daya manusia.

\section{Daftar Pustaka}

Afriansyah, H. (2019). MANAJEMEN MUTU TERPADU. Jurnal Ilmiah Ilmu Pendidikan, 1. https://doi.org/https://doi.org/DOI 10.17605/OSF.IO/JXCQY

Rusdinal. (2015). Efektivitas Layanan Informasi yang Mengkombinasikan Metode Ceramah, Sosiodrama, dan Diskusi dalam Merubah Persepsi Siswa Tentang Disiplin Belaja. Konselor, 4(1), 1-9. Retrieved from http://ejournal.unp.ac.id/index.php/konselor/a rticle/view/6453/5103

Surahyo. (2015). IMPLEMENTASI

MANAJEMEN MUTU TERPADU DALAM SISTEM PENDIDIKAN, PERMASALAHAN DAN PEMECAHANNYA. Jurnal Didaktika Islamika, 5(1), 1-11. Retrieved from http://stitmkendal.ac.id/docs/jurnal/implemen tasi_manajmen_mutu_terpadu_dalam_sistem 
_pendidikan_permasalahan_dan_pemecahan

nya_0.pdf

Pelaksanaan Permasalahan Serta Solusi Manajemen Mutu Terpadu dalam Sistem Pendidikan, Padang 2019 